\title{
The Impact of Study Abroad on the Global Engagement of University Graduates
}

\section{Dianna Murphy}

University of Wisconsin-Madison

\section{Narek Sahakyan}

University of Wisconsin-Madison

\section{Doua Yong-Yi}

University of Wisconsin-Madison

\section{Sally Sieloff Magnan}

\section{University of Wisconsin-Madison}

Study abroad is typically seen as a primary vehicle for building students' global competence. It is thus increasingly viewed on many U.S. college and university campuses as a "high-impact educational practice" (Kuh \& Schneider, 2008) that is a critical part of internationalization (see de Wit, 2002, for an historical review). The belief is that study abroad will better prepare graduates to meet opportunities and challenges in an increasingly globalized and interdependent world (e.g., Hser, 2005), that is, study abroad will produce "global citizens."

As the profession struggles to justify the link between study abroad and global competence, even the characterization of what it means to be globally competent is debated. Davies (2006) considers the term "global citizens" to be overly abstract. Traits defining global competence range from cross-cultural competencies and interpersonal skills in problemsolving, (Matherly \& Nolting, 2007) to intercultural awareness (Rexeisen, Anderson, Lawton, \& Hubbard, 2008) including general awareness of the wider world, outrage at social injustice, community engagement, and the desire to make the world a more sustainable place (Woolf, 2010, p. 50, citing the Oxfam Education website). According to Woolf (2010) being a global citizen "usually describes someone who is, or who aspires to be, broad minded, intellectually engaged with other cultures, aware of the interdependence of nations, committed to tolerance and understanding of difference" (p. 48), which he sees as an "aspirational, even utopian view of the world" (p. 52).

Still, this institutional and curricular interest in study abroad as a key internationalizing experience for students is reflected in rising numbers of students who participate in study abroad programs: According to the 2012 Open Doors "Fast Facts," 273,996 U.S. students studied abroad in 2010-11, an increase of $1.3 \%$ from the previous year and a threefold 
augmentation over the past twenty years (Institute of International Education, n. d.). Despite the growth in the numbers of participants, and the attention in the news media to the "record numbers" of U.S. students studying abroad (Mach, 2011), the total proportion of U.S. students who study abroad remains remarkably low: only $1.3 \%$ of all students enrolled in U.S. institutions of higher education in the United States studied abroad in the 2009-10 academic year (NAFSA: Association of International Educators, 2011). ${ }^{1}$

Given the low participation rate in study abroad, U.S. educators, as well as other stakeholders in the internationalization of postsecondary education, should consider the extent to which study abroad promotes the development of global competence, as well as the ways in which study abroad might have a salutary impact on behaviors that are beneficial for the broader society as well as for the individual. As research accumulates to show this impact, the institutional investment in study abroad programs can be more readily justified not only in terms of the benefits to participants, but also in terms of how study abroad relates to the greater common good.

Hadis (2005) argued that, although the research findings on the impact of study abroad often support impressionistic perceptions that participants acquire global-mindedness, such research suffers from small sample sizes and lack of control groups. Indeed many studies measure intercultural development in a pre-/post- or just post-study abroad design (e.g., Engle \& Engle, 2004; Paige, Cohen, \& Shively, 2004) that cannot show whether students who did not study abroad would have developed the same level of global awareness and sensitivity through their experiences on their home campus. Studies with control groups most often compare students studying abroad with those studying at home, comparing their outcomes especially in language gain (see Magnan \& Lafford, 2012, for a discussion of research methods used), whereas claims about how study abroad builds global citizenship extend to programs that are not language focused. Chieffo and Griffiths (2004) examined whether study abroad students acquired global awareness to a greater extent than did students taking similar classes at home. Defining global awareness as intercultural awareness, personal growth and development, awareness of global interdependence, and functional knowledge of world geography and language, they found that study abroad students were "more confident in their levels [of] intercultural awareness and functional knowledge than their peers who remained on campus" (p. 167).

A major issue with this body of research is its focus on short-term impact. As Franklin (2010) stated: "study abroad outcomes assessments are routinely conducted immediately following a participant's return from abroad or shortly after graduation" (p. 169). Indeed, this focus is common when examining study abroad in terms of outcomes related to language learning (see Kinginger, 2009, for a recent review), changes in beliefs or attitudes about language learning (Amuzie \& Winke, 2009) and culture (Carlson \& Widaman, 1988), as well as the development of intercultural competence (for reviews, see Perry \& Southwell, 2011, and Salisbury, 2011). In contrast, developing global citizens is clearly a long-term outcome. 
Viewing a longer life trajectory, a number of studies have investigated the impact of study abroad on behavioral outcomes (Rowan-Kenyon \& Niehaus, 2011), teaching transformation (Sandgreen, Elig, Hovde, Krejci \& Rice, 1999), academic achievement (Akande \& Slawson, 2000; Dwyer, 2004a; Fry, Paige, Jon, Dillow, \& Nam, 2009; Redden, 2010; Sutton \& Rubin, 2004, 2010; University of Indiana, 2009), and career performance (Norris \& Gillespie, 2009; Teichler \& Janson, 2007). Especially in the last decade, research has focused increasingly on the longer-term impact of study abroad. Alred and Byram (2005), for example, interviewed alumni of British year-abroad programs ten years after study abroad to explore long-term intercultural learning. With a tracer study of alumni of study abroad programs, the Institute for the International Education of Students (IES) surveyed five decades of IES alumni (Dwyer, 2004b; Dwyer \& Peters, 2004) to suggest that the experience abroad had a long-term impact on students' later academic achievement, career direction, and intercultural and personal growth (Dwyer, 2004a; Norris \& Dwyer, 2005; Norris \& Gillespie, 2005). Bachner and Zeutschel (2008, 2009) reached similar conclusions through a study of the long-term impact of the Youth for Understanding program. More recently, Franklin (2010) looked at alumni ten years after graduation to reveal the impact of study abroad on participants' personal lives.

Focusing centrally on the effect of study abroad on both the lives of study abroad alumni and their impact on society more broadly, Paige and colleagues undertook a large study of 6,391 U.S. alumni from 22 programs from 1950-2007 (Study Abroad for Global Engagement, SAGE; Paige, Fry, Stallman, Josic, \& Jon, 2009). The SAGE study drew on Allport's $(1954,1958,1979)$ social contact theory on the nature of prejudice to define global engagement through five self-reported domains: "(a) civic engagement in domestic and international arenas; (b) knowledge production of print, artistic, online and digital media; (c) philanthropy, in terms of volunteer time and monetary donations; (d) social entrepreneurship, involvement in organizations whose purpose and/or profits are to benefit the community; and the practice of (d) voluntary simplicity in one's lifestyle (italics added)" (Paige et al., 2009, p. S30). Findings from the SAGE study showed high levels of positive responses to many questions relating to these global engagement domains. Based on these findings, and to positive responses to questions about the influence of study abroad on these behaviors, the researchers concluded that study abroad has a positive impact on the global engagement of alumni, claiming that "when we look at the percentage of participants who become civically involved, produce new knowledge and practice new and environmentally aware lifestyles, make philanthropic commitments and create or participate in social entrepreneurship, it is unlikely that these findings would pertain in the larger population (italics added)" (p. S41).

The conceptual model for global engagement put forth by SAGE is intriguing. It takes into account the notions of civic/community engagement, of volunteerism, and, through the domain of voluntary simplicity, the desire to make the world a more sustainable place, considered important by Oxfam (in Woolf, 2010) and by Reilly and Senders (2009). With volunteerism, it especially includes philanthropy, an outcome found in Franklin (2010), which the authors related to internationalization of study abroad graduates. It refines the 
typically included domains of knowledge to the production of knowledge, and of career enhancement to social entrepreneurship.

Although the conceptual model and findings from the SAGE study are compelling, the concluding statement that similar levels of global engagement are not likely to be found in the broader population reveals a major limitation in the study's design: the absence of a control group of participants that did not study abroad. This weakness was called out by Franklin (2010) for her study as well. The question remains an empirical one: Are the levels of global engagement reported in the SAGE study in fact higher than the global engagement of individuals who did not study abroad? If the levels of global engagement are higher among alumni of study abroad programs than of alumni who did not study abroad, it would provide support for the conclusion made by Paige and others that participation in study abroad has a long-term impact on the subsequent global engagement of alumni. If they are not, the validity of the findings reported by SAGE might be called into question.

\section{The Present Study}

The present study addresses this limitation of the SAGE study by comparing the global engagement of alumni who did and did not study abroad, offering new insights into the findings from the SAGE project and new contributions to the profession's understanding of the long-term social impact of study abroad. The study builds on the SAGE project by examining the long-term, social impact of study abroad through a comparison of the global engagement of groups of alumni from the same U.S. institution who did and did not study abroad as undergraduates.

Global engagement was measured according to self-reported behaviors associated with the five global engagement domains conceptualized for the SAGE study (civic engagement, knowledge production, philanthropy, social entrepreneurship, and voluntary simplicity), and a new sixth dimension (internationally-oriented leisure activities), revealed as a positive outcome of study abroad by Chieffo and Griffith's (2004) study.

The study seeks to answer the following research questions: Are alumni of study abroad programs more globally engaged than alumni who did not study abroad as undergraduates? Is there a difference in the different dimensions of global engagement of alumni who did and did not study abroad as undergraduates?

\section{Methodology}

The study was based on a written questionnaire, modelled closely on the Global Engagement Survey (Paige et al., 2007) developed for the SAGE project, and administered online to alumni of a U.S. university who graduated between 1980 and $2010 .^{2}$

Participants. Participants in the study $(\mathrm{N}=1,283)$ were alumni of B.A. or B.S. degree programs at the University of Wisconsin-Madison (UW-Madison), a large, public university in the midwestern region of United States. UW-Madison is one of the top ten in the United 
States in the number of students who participate in study abroad (Chow \& Bhandari, 2011, p. 88), as well as one of the top producers of volunteers to the Peace Corps. ${ }^{3}$ With a strong institutional commitment to international education, and explicitly stated learning outcomes for all students that target the development of "civic knowledge and engagement - local and global" (Office of the Provost for Teaching and Learning, n.d.), the researchers anticipated that the level of global engagement of alumni would be high regardless of study abroad participation, and that any differences found between the groups of alumni who did and did not study abroad would thus be particularly meaningful.

Participants were comprised of two groups of alumni who completed the Bachelor's degree between 1980 and 2010. The first group ( $n=270$, Study Abroad group) participated in one of eleven semester- or year-long programs in one of seven countries (see Appendix A). The second group ( $n=1,013$, No Study Abroad group) were alumni of the same university with a similar profile to the first group in terms of year of graduation, school or college of major field of study, and single or multiple major, but who did not study abroad as undergraduates.

The researchers checked for differences between the Study Abroad and No Study Abroad groups to rule out possible confounding variables that might be relevant in explaining the differences between the two groups in global engagement, such as parental income, languages spoken at home, languages spoken by parents in professional contexts, parental participation in study abroad, or childhood residence outside of the United States. The statistical analysis revealed that these variables were not statistically different across the two groups.

Questionnaire. The instrument was an online questionnaire based on the Global Engagement Survey (GES) developed for the SAGE study. The GES was designed to examine the link between the study abroad experiences of alumni of U.S. universities and their later participation in activities associated with global engagement in five domains: civic engagement, knowledge production, philanthropy, social entrepreneurship and voluntary simplicity. Table 1 shows how these domains were operationally defined in the questionnaire.

Table 1. Operational Definitions of Global Engagement Domains in the Global Engagement Survey. Based on Paige et al. 2007.

\begin{tabular}{|l|l|}
\hline Global engagement domain & Operational definition \\
\hline $\begin{array}{l}\text { Civic engagement } \\
\text { items) }\end{array}$ & $\begin{array}{l}\text { On issues of domestic or international importance, participation in } \\
\text { activities such as voting in an election, playing a leadership role in } \\
\text { improving the quality of life, using the Internet to raise awareness } \\
\text { about social or political issues, making a purchasing decision } \\
\text { because of the social or political values of a company, or contacting } \\
\text { or visiting a public official. }\end{array}$ \\
\hline $\begin{array}{l}\text { Knowledge production } \\
\text { (5 items) }\end{array}$ & $\begin{array}{l}\text { Creation of new knowledge by sharing ideas through publication in } \\
\text { print or other media. }\end{array}$ \\
\hline $\begin{array}{l}\text { Philanthropy } \\
(6 \text { items) }\end{array}$ & $\begin{array}{l}\text { Participation in volunteer activities or donation of money or assets to } \\
\text { organizations devoted to the arts, community, education, } \\
\text { environment, health, human rights, international development, } \\
\text { poverty, religion, social justice, and youth organizations. }\end{array}$ \\
\hline Social entrepreneurship & Involvement in creating a new organization that has social objectives \\
\hline
\end{tabular}




\begin{tabular}{|l|l|}
\hline (7 items) & $\begin{array}{l}\text { as its primary goal, or influencing a for-profit organization to devote } \\
\text { part of its profits for the good of the community. }\end{array}$ \\
\hline $\begin{array}{l}\text { Voluntary simplicity } \\
(2 \text { items })\end{array}$ & The effort to lead a more modest, simple lifestyle. \\
\hline
\end{tabular}

The items in the questionnaire for the present study were based on those in the GES, with slight revisions in wording for clarity, made after a pilot study. The SAGE questionnaire was further modified for the present study to create branched sets of questions for the two groups of participants: only the Study Abroad group responded to questions about their study abroad experience, or about the influence of study abroad on behaviors associated with global engagement.

To explore the long-term impact of study abroad on the enrichment of participants' lives, and recognizing the importance of interaction in the development of intercultural competence (Byram, 1997), the present study expanded the model of global engagement in the SAGE project to include an additional global engagement domain that addressed interactions with both people and products of other cultures purely for personal pleasure. This new domain, internationally-oriented leisure activities, was defined operationally through five items that asked participants to self-report on their friendships with people from other cultures, and their engagement in behaviors such as traveling internationally for pleasure, accessing media in other languages, trying new international cuisines, taking language classes and hosting international visitors. It thus picked up on the "internationally minded activities" and learning in "broader and non-academic categories" described by Chieffo and Griffiths (2004, p. 175).

The 28 questions addressing global engagement in the online questionnaire are in Appendix B. The majority of questions followed a fixed-response, yes/no or Likert-scale response format, with the exception of several free-response items for which participants responded to questions about time (e.g., number of hours volunteering each month), dollar amounts (e.g., annual household income), or count items (e.g., number of works published).

\section{Procedures}

Sampling. Lists of participants for the Study Abroad group were compiled from university study abroad records. The researchers then worked with the university's alumni office to obtain data on year of graduation, school or college of major field of study, and number of majors, as well as current contact information. The No Study Abroad group participants were identified by randomly sampling a sub-set of the university's alumni database comprised of those alumni who had similar characteristics to the Study Abroad group. The researchers anticipated that the response rate for the No Study Abroad group would be considerably lower than for the Study Abroad group, so the sample size for the No Study Abroad group was approximately four times that of the Study Abroad group.

Data collection. The questionnaire was administered online through email solicitations to participants. Data were collected in two phases, preceded by a pilot, in 2010 and 2011. 
The response rates were 22\% for the Study Abroad group and 13\% for the No Study Abroad group, which is in line with the 23\% response rate of the 2002 IES study (Rexeisen, Anderson, Lawton, \& Hubbard, 2008) and Hadis's (2005) 14\% response rate on his voluntary online survey.

Data analysis. Responses to the online questionnaire were exported from the survey website and subjected to a rigorous data preparation and cleaning phase to delete out-ofrange and invalid observations. The statistical analysis was performed using the statistical software STATA 12.

To answer the research questions regarding differences in the global engagement of alumni who did and did not study abroad, and to compare the profiles of the two groups, appropriate non-parametric methods and statistical hypothesis tests were used to confirm or reject across-group differences: (a) an extension of the Wilcoxon signed-rank test (nptrend in Stata) was used for response items measured on a Likert scale; (b) a proportion test (prtest in Stata) was used to compare response items representing count outcomes; (c) a two-group test of means (ttest in Stata) was used for other free entry items (e.g., number of hours volunteering). Across-group differences were considered significant at the $95 \%$ confidence level, or $\mathrm{p}<0.05$. To display the findings, charts were created to show percentages of positive responses to all Likert-scale responses for the two groups of participants. ${ }^{4}$

\section{Findings and Discussion}

The research questions asked if alumni of study abroad programs were more globally engaged than alumni who did not study abroad as undergraduates. The findings for this

question are presented below by global engagement domain, beginning with civic engagement.

\section{Civic Engagement}

Civic engagement was defined as participation activities such as voting in an election and playing a leadership role in improving quality of life. As shown in Figure 1, alumni in the Study Abroad group were more likely than alumni in the No Study Abroad group to report higher levels of participation in behaviors associated with civic engagement on issues of international importance for all items pertaining to civic engagement on the questionnaire (on the $\mathrm{x}$-axis in Figure 1; statistical significance between the two groups of participants is marked by an asterisk in all figures, $\mathrm{p}<0.05)$. This finding suggests support for the claim by Paige and colleagues (2009) that the levels of civic engagement shown by alumni of study abroad programs would not be found in the broader population, at least on issues of international importance. As shown in Figure 1, the difference between the two groups was greatest for the item on consumer behavior (making a purchasing decision based on the social values of the company): Study Abroad group, 64\%; No Study Abroad group, 48\%. 
Figure 1. Civic Engagement: Issues of International Importance

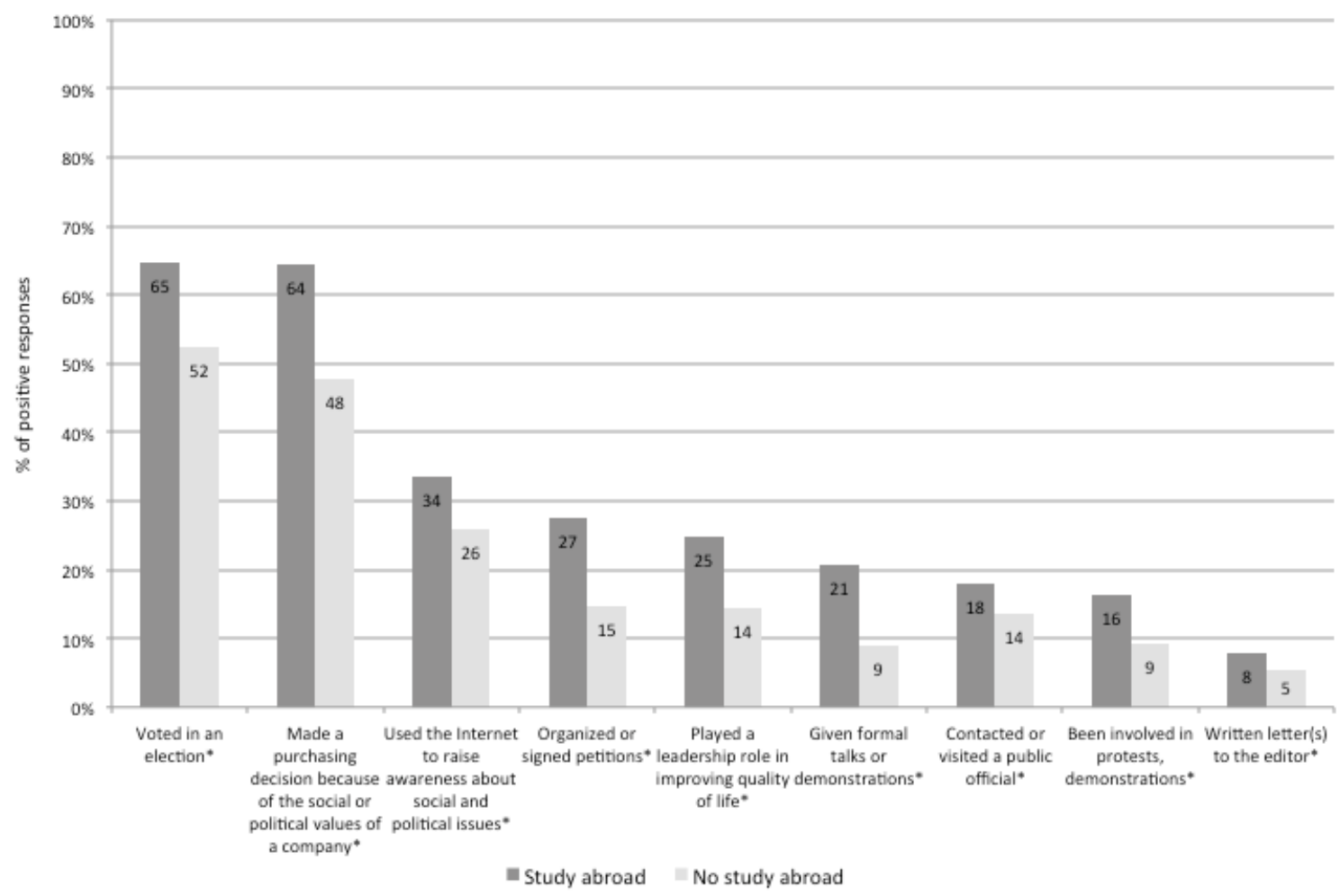

Considering civic engagement on issues of domestic importance, the picture is mixed, as shown in Figure 2. There was significant difference between the two groups, with the Study Abroad group showing higher levels of positive responses than the No Study Abroad group for only three of the nine items related to civic engagement: contacting or visiting a public official, making a purchasing decision based on the values of a company, and being involved in protests or demonstrations. There was no difference between the two groups for the remaining items related to civic engagement on issues of domestic importance.

The aspect of domestic civic engagement that Paige and colleagues (2009) reported as being highest for domestic civic engagement was voting in an election, with $92 \%$ positive responses (p. S37); this aspect was highest in this study as well, but with no difference between the Study Abroad and the No Study Abroad groups (the positive responses were $98 \%$ and $96 \%$ respectively), suggesting that the claim made by Paige et al. that there would not be similar levels of global engagement in the broader population is not true in all cases. 
Figure 2. Civic Engagement: Issues of Domestic Importance

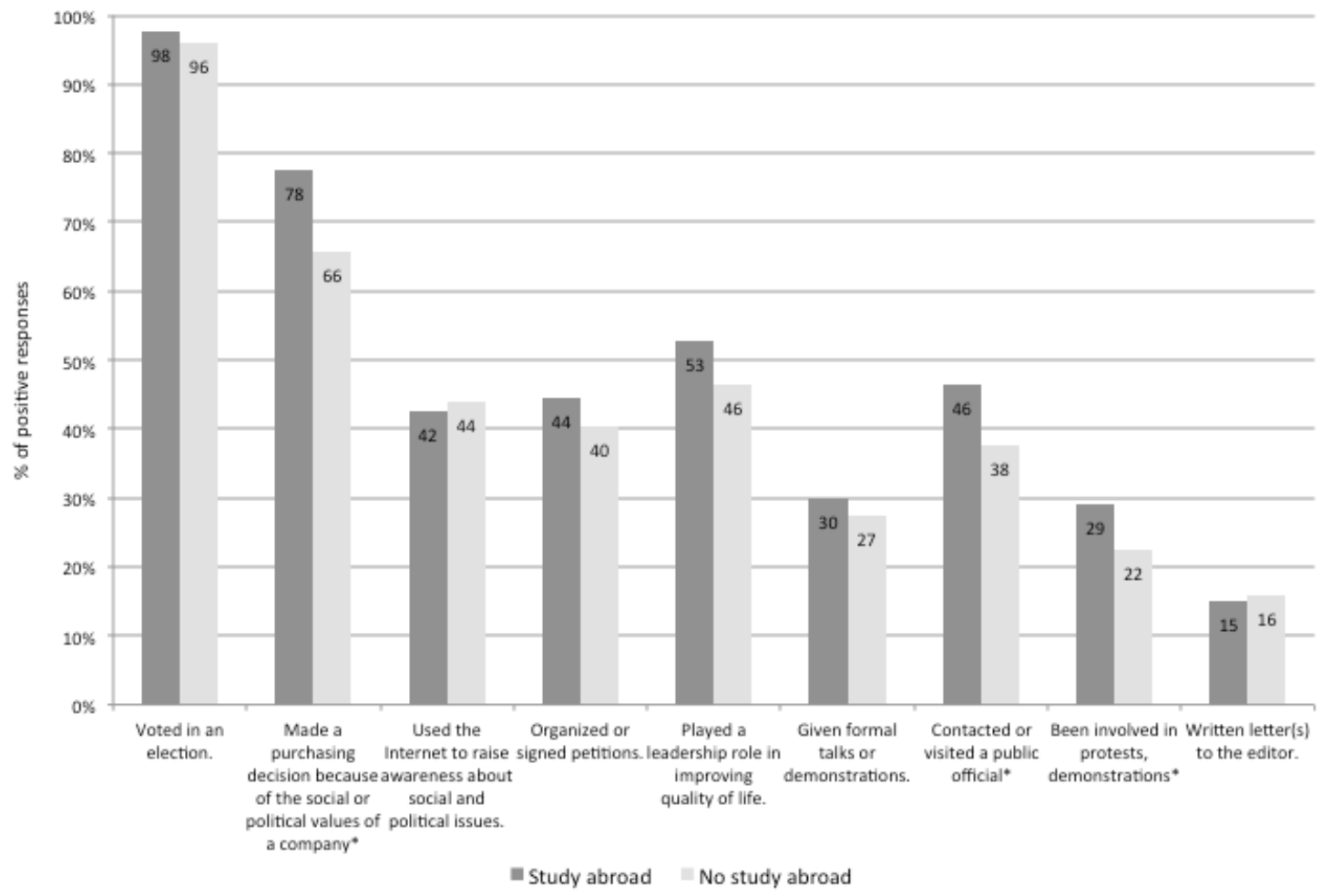

Considering just the level of engagement, Paige and colleagues reported that study abroad alumni had higher overall levels of civic engagement on issues of domestic, rather than international, importance. The present study confirms this finding: the mean response for all questions on domestic civic engagement was 1.41 , compared to 0.94 for questions on international civic engagement. Although the levels of international civic engagement were lower than the levels of domestic civic engagement for both groups, it is in the area of international civic engagement in which we found more and greater differences between the Study Abroad and No Study Abroad groups. This result suggests that study abroad may have a greater impact on international, rather than domestic, civic engagement. This finding, while perhaps not surprising, should certainly be welcomed by educators who hope that study abroad will positively affect the engagement of Americans in issues of global importance and concern.

\section{Voluntary Simplicity}

Voluntary simplicity was defined as the effort to lead a more modest, simple lifestyle. The analysis revealed significantly higher responses to the question about the degree of practice of voluntary simplicity: $88 \%$ of the Study Abroad group reported practicing voluntary simplicity (similar to SAGE's finding of $86 \%$ ), compared to $77 \%$ in the No Study Abroad group. Moreover, 67\% of the Study Abroad group indicated that their study abroad 
experience influenced them to practice voluntary simplicity, providing support for an interpretation that the study abroad experience can explain the difference between the two groups. This finding regarding voluntary simplicity provides further support for a claim that study abroad affects consumer behavior.

\section{Philanthropy}

Philanthropy was measured both in terms of the volunteering of time, and in terms of monetary donations to different kinds of organizations devoted to promoting the common good. The findings regarding philanthropy were mixed. Regarding volunteering, SAGE reported that $55 \%$ of alumni of study abroad programs volunteered for an educational organization; 49\% volunteered for community organizations (Paige et al. 2009, p. S37). The responses for the Study Abroad group were remarkably similar in the present study (See Figure 3.) Comparing the responses of the two groups of alumni, our study found that the Study Abroad group was significantly more likely than the No Study Abroad group to have volunteered for organizations devoted to the arts, education, the environment, human rights, international development and social justice. The No Study Abroad group, however, was significantly more likely to have volunteered for youth organizations. There was not a statistically significant difference between the two groups in volunteering for other types of organizations.

Figure 3. Philanthropy: Volunteering

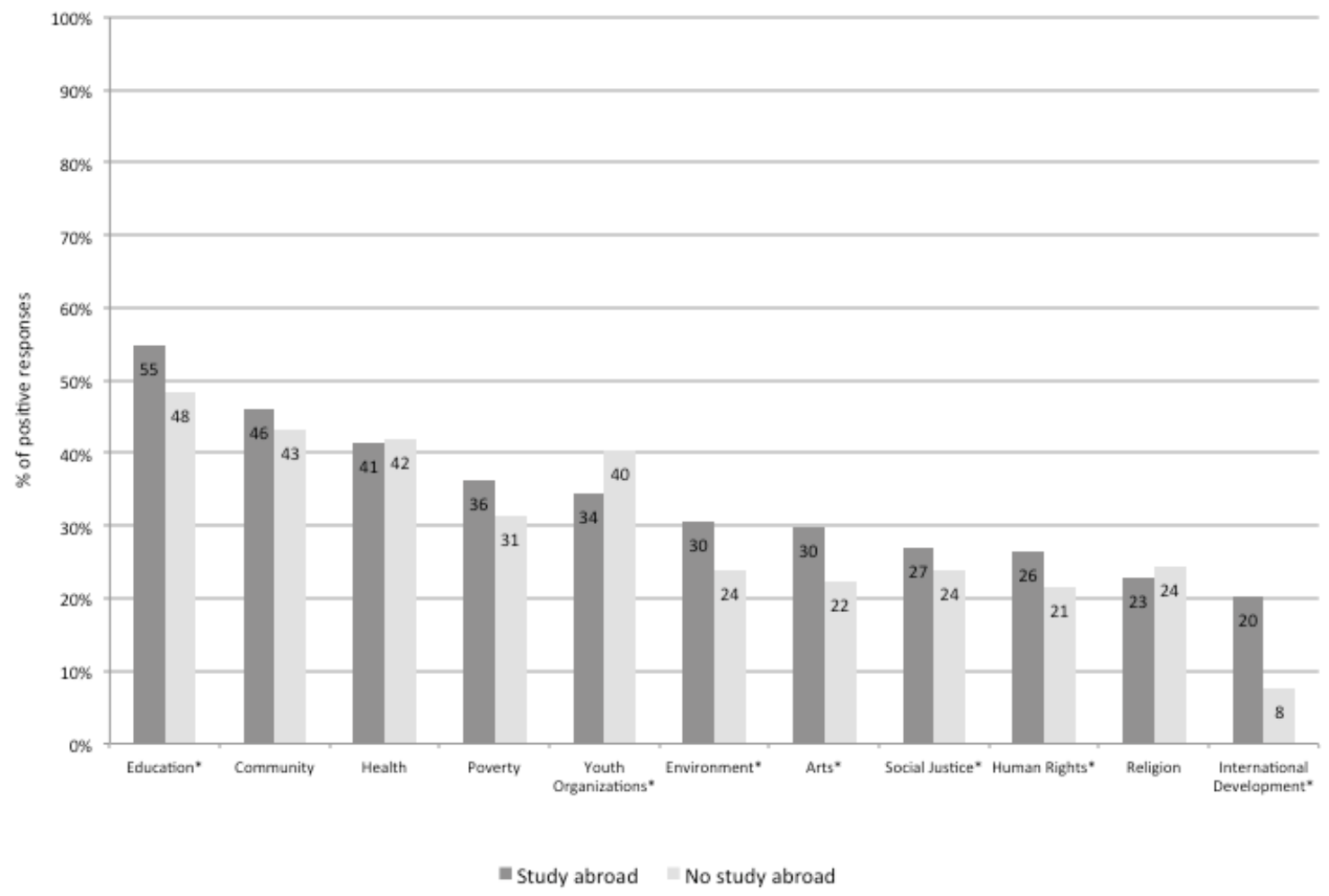


Regarding monetary donations, the Study Abroad group was significantly more likely than the No Study Abroad group to have made monetary contributions to many of the same types of organizations for which they volunteered (arts, education, environmental, human rights, international development, social justice); the No Study Abroad group was significantly more likely than the Study Abroad group to have made monetary donations to youth organizations and religious organizations. There were no significant differences between the two groups in philanthropic donations of time or money to organizations devoted to community, health, or poverty.

These mixed findings regarding philanthropy thus suggest that study abroad may have an impact on philanthropic activities in some areas, but not in others. The greatest difference between the two groups in philanthropy was in international development, the environment and education findings, suggesting that the study abroad experience may heighten participants' awareness of needs in those areas especially.

\section{Knowledge Production}

The SAGE study reported that 39\% of alumni had something published in their lifetime (Ibid.); the findings from the present study were similar (37\% positive responses for the Study Abroad group; 40\%, for the No Study Abroad group). The nptrend test for ordinal differences, however, revealed no significant difference between the two groups in the number of works published; moreover, the No Study Abroad group showed a higher response. This finding could be interpreted to suggest that study abroad does not appear to have an impact on knowledge production. The authors caution against this interpretation, however: the impact of study abroad may not be in the quantity of works published, but in the type of new knowledge created. Looking at the kinds of works published, we find that the Study Abroad group was significantly more likely than the No Study Abroad group to have published works with an international or intercultural orientation (10\% for the Study Abroad group, compared to $4 \%$ for the No Study Abroad group), and to have published scholarly non-fiction ( $5 \%$ vs. $2 \%$ ).

\section{Social Entrepreneurship}

The present study did not find differences between the two groups on items related to social entrepreneurship, suggesting that, like knowledge production, the domain either may not be of particular relevance in assessing the impact of study abroad, or did not capture the salient aspects of this domain; or, there really may be no differences between alumni who did and did not study abroad in this domain of global engagement.

\section{Engagement in Internationally-Oriented Activities for Personal Enjoyment or Leisure}

This final domain, added to the SAGE model by the researchers of the present study, reveals striking differences between the two groups of participants. First, the Study Abroad group reported maintaining significantly higher number of friends from cultures other than 
their own than did the No Study Abroad group, suggesting a higher level of personal engagement with people of other cultures more generally. Almost all respondents of the Study Abroad group (96\%) reported maintaining friendships with people of cultures different from their own, compared to $85 \%$ for the No Study Abroad group. Considering engagement in internationally-oriented activities, Figure 4 shows that the Study Abroad group was significantly more likely than the No Study Abroad group to report engaging in every type of leisure activity assessed in the study: cook international cuisine, travel internationally for pleasure, watch films or listen to music in a language other than English, go to restaurants to try new international cuisine, access foreign websites, read international newspapers, journals or magazines, attend talks or presentations with an international focus, take language classes, and host international visitors. These findings show that alumni of study abroad programs are more likely than their peers to engage in behaviors that involve a connection with peoples or the material products of other cultures, providing at least the necessary preconditions for developing intercultural competence and, it stands to reason, global engagement. This finding supports a similar finding of Chieffo and Griffiths (2004), which served as inspiration for adding this dimension.

Figure 4. Internationally-oriented Leisure Activities

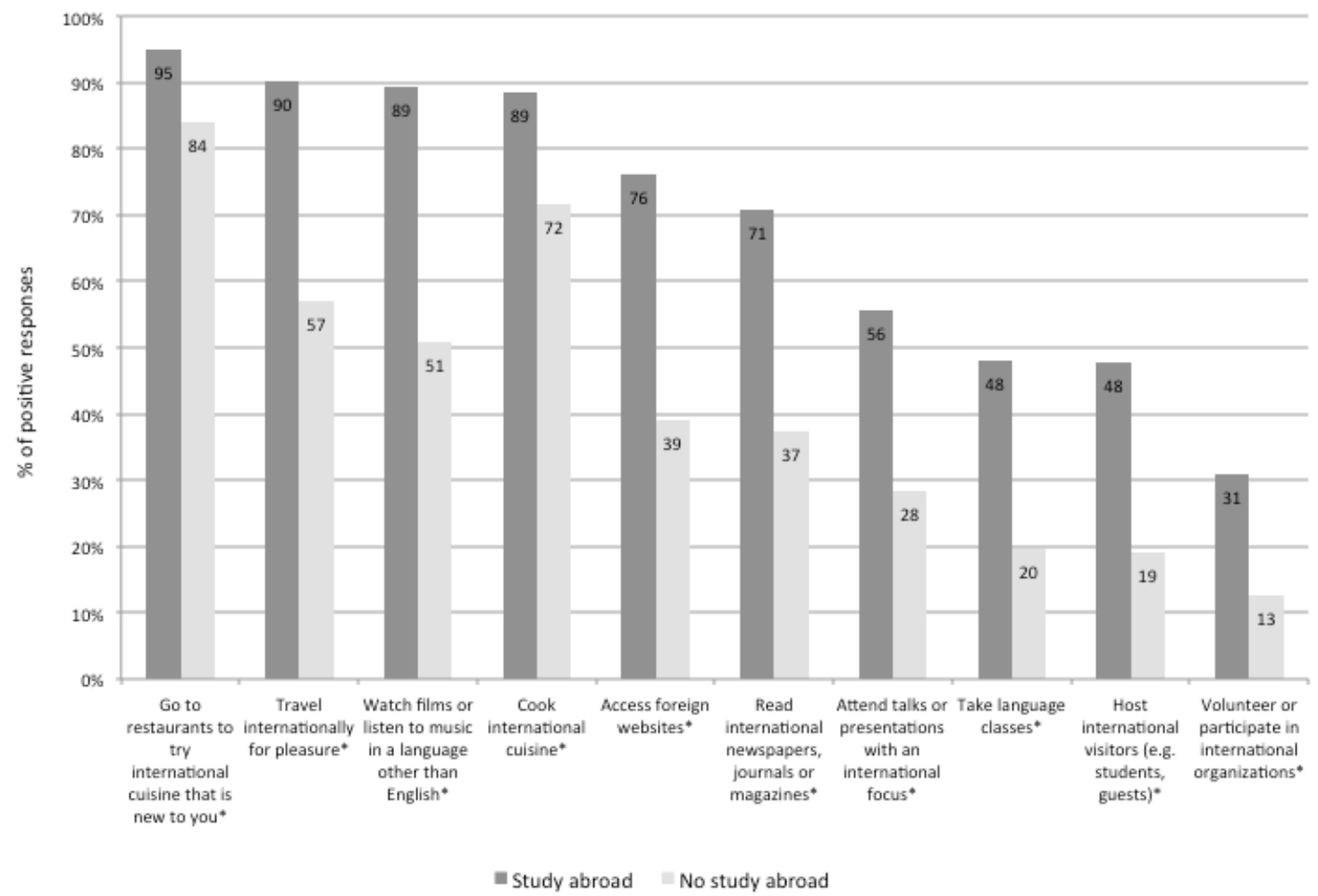


To summarize the findings, the research questions asked if alumni of study abroad programs were more globally engaged than alumni who did not study abroad as undergraduates, and if there was a difference in the different dimensions of global engagement of alumni who did and did not study abroad as undergraduates. Findings from this study provide a mixed answer. Findings show that in comparison with peers who did not study abroad as undergraduates, alumni of study abroad programs showed higher levels of civic engagement in all areas on issues of international importance, and higher levels of civic engagement in some areas on issues of domestic importance; higher levels of voluntary simplicity; and higher levels of philanthropic activity for organizations devoted to the arts, education, environmental, human rights, international development, social justice. There were striking differences between the two groups in the activities in which they engage for personal enjoyment, with alumni of study abroad reporting much higher levels of engagement in internationally-oriented leisure activities. There was no difference in the two groups in terms of social entrepreneurship or in knowledge production, at least in terms of the quantity of output and in the context of these data.

\section{Need for Continued Research}

This study addressed one of the major limitations of the SAGE study by including a control group of alumni who did not study abroad. It did not, however, control for the possibility that the higher levels of global engagement found (in some domains) among alumni who studied abroad were not the result of the study abroad experience itself, but indicative of inherent or pre-existing characteristics of individuals who were inclined to study abroad. Such possible selection bias was identified by Miller-Perrin and Thompson (2010) whose control group scored higher on identity achievement than students who chose to study abroad, when both were assessed during their first year of college prior to a study abroad experience.

In the present study, the researchers attempted to address the potential for selection bias by including a third group of participants: alumni of the same university who indicated interest in study abroad, but who did not end up studying abroad for some reason. Participants for this group included individuals who attended an information session about a study abroad program; started, but did not complete, an application for a study abroad program; or applied to study abroad but did not go. Unfortunately, the sample size for this group was not large enough to be included in the analysis. Hadis (2005) also tried to have such a control group but also did not receive enough responses from members of that group. Although the comparison between students who studied abroad and those who did not is a major step forward, the successful inclusion of a group sharing characteristics with the study abroad group but not having that experience should be a primary objective for future research.

In addition, the profession must continue to consider what it means to be globally competent and the concepts underlying this definition. Further refinement of the notion of global competence will bring both depth and nuance to research and thereby to our 
understanding of how developing intercultural sensitivities and abilities relates to study abroad.

\section{Conclusions}

Citizens who are civically engaged, practice voluntary simplicity, make philanthropic donations of time and money to organizations devoted to the common good, who have friendships with people from other cultures, and who engage in internationally-oriented activities for personal enjoyment or leisure, enrich not only their own lives, but the larger communities in which they live and work. This study expanded on the work of Paige and colleagues for the SAGE project to assess the long-term impact of study abroad on the global engagement of alumni. Its findings support the claim by SAGE that study abroad at the undergraduate level has a salutary and long-term social impact, by demonstrating that alumni who studied abroad had higher levels of some types of global engagement than alumni who did not study abroad as undergraduates. The study suggests that further research is warranted, to address the possibility that inherent or pre-existing characteristics of study abroad participants, and not just the study abroad experience alone, might account for some of the differences found in the levels of global engagement between the two groups. Nevertheless, the findings should encourage universities to continue to develop and promote study abroad programs for their students, not only as part of internationalization efforts, but to promote the development of a socially-connected citizenry that participates in the civic life of the community to promote the common good.

\section{Notes}

1. The percentage of undergraduates who study abroad varies widely by state, from $.29 \%$ (Alaska) to $4.45 \%$ (Vermont). Study abroad enrollment for Wisconsin, the state in which research for the present study was conducted, was $2.03 \%$ of the total enrollment in degree-granting postsecondary institutions. This national and state data was compiled by NAFSA, based on data from the Institute for International Education and the U.S. Department of Education's National Center for Education Statistics.

2. The study was reviewed and approved by the human subjects Institutional Review Board at the university at which the study was conducted (protocol \# SE-2009-0790).

3. http://www.peacecorps.gov/index.cfm?shell=resources.media.press.view\&news_id=1955.

4. Positive responses were frequently, sometimes for questions about frequency of engagement in the behavior; yes, for yes/no questions; to a large degree, to some degree, for questions about the degree of engagement in the behavior or the influence of study abroad.

\section{Acknowledgments}

The authors gratefully acknowledge the many contributions to this research by Rob Howell, former director, University of Wisconsin-Madison International Academic Programs, and by the staff of UW-Madison International Academic Programs, the Wisconsin Alumni Association, and the Language Institute. They also benefitted greatly from the work 
of graduate student assistants Alice Astarita, Clara Salto Weis Azevedo, and Carolina Bailey. Although the authors were unable to obtain an adequate amount of data for a participant group comprised of alumni who had wanted to study abroad but did not, the authors thank Nicholas Magnan, University of Georgia, for this important idea, and hope that it can be implemented in future studies. Funding for this research was from a grant from the University of Wisconsin-Madison Office of the Provost.

\section{References}

Akande, Y., \& Slawson, C. (2000). Exploring the long-term impact of study abroad: A case study of 50 years of study abroad alumni. International Educator, 9(3), 12-17.

Allport, G. W. (1979, 1958, 1954). The nature of prejudice. Cambridge, MA: Perseus Books. Alred, G., \& Byram, M. (2005). British students in France: 10 years on. In M. Byram \& A. Feng (Eds.), Living and studying abroad: Research and practice (pp. 210-231). Clevedon, UK: Multingual Matters.

Amuzie, G. L., \& Winke, P. (2009). Changes in language learning beliefs as a result of study abroad. System, 37(3), 366-379. doi:10.1016/j.system.2009.02.011

Bachner, D., \& Zeutschel, U. (2008). Students of four decades: Participants' reflection on the meaning and impact of an international homestay experience. New York: Waxman.

Bachner, D., \& Zeutschel, U. (2009). Long-term effects of international educational youth exchange. Intercultural Education, 20(S1-2), S45-58. doi:

$10.1080 / 14675980903370862$

Byram, M. (1997). Teaching and assessing intercultural communicative competence. Clevedon, UK: Multilingual Matters.

Carlson, J. S., \& Widaman, K. F. (1988). The effects of study abroad during college on attitudes toward other cultures. International Journal of Intercultural Relations, 12(1), 117.

Chieffo, L., \& Griffiths, L. (2004). Large-scale assessment of student attitudes after a shortterm study abroad program. Frontiers: The Interdisciplinary Journal of Study Abroad, 10, 165-177. Retrieved from http:/www.frontiersjournal.com/issues/vol10/vol1010_ChieffoGriffiths.pdf

Chow, P., \& Bhandari, R. (2011). Open doors: Report on international educational exchange. New York: Institute of International Education.

Davies, L. (2006). Global citizenship: Abstraction or framework for action? Educational Review, 58(1), 5-25. doi: 10.1080/00131910500352523

de Wit, H. (2002). Internationalization of higher education in the United States of America and Europe: A historical, comparative, and conceptual analysis. Westport, CT: Greenwood Press.

Dwyer, M. M. (2004a). Charting the impact of studying abroad. International Educator, 13(1), 14-17 and 19-20.

Dwyer, M. M. (2004b). More is better: The impact of study abroad program duration. Frontiers: The Interdisciplinary Journal of Study Abroad, 10, 151-164. Retrieved from 
http://www.frontiersjournal.com/issues/vol10/vol10-09_Dwyer.pdf

Dwyer, M. M., \& Peters, C. K. (2004, March/April). The benefits of study abroad: New study confirms significant gains. Transitions Abroad Magazine. Retrieved from http://www.transitionsabroad.com/publications/magazine/0403/benefits_study_abroad. shtml

Engle, L., \& Engle, J. (2004). Assessing language acquisition and intercultural sensitivity development in relation to study abroad program design. Frontiers: The Interdisciplinary Journal of Study Abroad, 10, 219-236. Retrieved from http://www.frontiersjournal.com/issues/vol10/vol10-13_EngleEngle.pdf

Franklin, K. (2010). Long-term career impact and professional applicability of the study abroad experience. Frontiers: The Interdisciplinary Journal of Study Abroad, 19, 169-190. Retrieved from http://www.frontiersjournal.com/documents/Frontiers_XIX_Fall_2010_K_Franklin.pdf

Fry, G. W., Paige, R. M., Jon, J., Dillow, J., \& Nam, K. (2009). Study abroad and its transformative power (CIEE Occasional Paper 32). Retrieved from http://www.ciee.org/home/researchpublications/documents/CIEEOccasionalPapers32.pdf

Hadis, B. F. (2005). Why are they better students when they come back? Determinants of academic focusing gains in the study abroad experience. Frontiers: The Interdisciplinary Journal of Study Abroad, 11, 57-70. Retrieved from http://www.frontiersjournal.com/documents/BFHadisFrontiersAug05.pdf

Hser, M. P. (2005). Campus internationalization: A study of American universities' internationalization efforts. International Education, 35(1), 35-48.

Institute of International Education. (n.d.). Open doors 2012: Fast facts. Retrieved from http://www.iie.org/Who-We-Are/News-and-Events/Press-Center/PressReleases/2012/11-13-2012-Open-Doors-International-Students

Kinginger, C. (2009).Language learning and study abroad: A critical reading of research. Basingstoke: Palgrave Macmillan.

Kuh, G. D., \& Schneider, C. G. (2008). High-impact educational practices: What they are, who has access to them, and why they matter. Washington, DC: Association of American Colleges and Universities.

Mach, A. (2011, November). Why Americans are choosing to study abroad in record numbers. Retrieved from http://www.csmonitor.com/USA/Education/2011/1114/WhyAmericans-are-choosing-to-study-abroad-in-record-numbers

Magnan, S., \& Lafford, B. (2012). Learning through immersion during study abroad. In S. Gass \& A. Mackey (Eds.), The Routledge handbook for second language acquisition (pp. 525-540). New York: Routledge.

Matherly, C., \& Nolting, W. (2007, Fall). Where to next? Career pathways. Abroad View, 10(1), 38-39.

Miller-Perrin, C., \& Thompson, D. (2010). The development of vocational calling, identity, and faith in college students: A preliminary study of the impact of study abroad. Frontiers: The Interdisciplinary Journal of Study Abroad, 19, 87-103. Retrieved from 
http://www.frontiersjournal.com/documents/PerrinMiller-ThompsonFrontiers_XIX_Fall_2010pdf.pdf

NAFSA: Association of International Educators. (2011, November). Study abroad participation by state 2009-2010. Retrieved from http://www.nafsa.org/uploadedFiles/NAFSA_Home/Resource_Library_Assets/Public_P olicy/state_by_state_2010.pdf

Norris, E. M., \& Dwyer, M. (2005). Testing assumptions: The impact of two study abroad program models. Frontiers: The Interdisciplinary Journal of Study Abroad, 11, 121-141. Retrieved from http://www.frontiersjournal.com/documents/EMohajeriNorrisMMDwyerFrontiersAug0 5.pdf

Norris, E. M., \& Gillespie, J. (2005, Spring). Study abroad: Stepping stone to a successful international career. NACE Journal, 65(3), 30-36.

Norris, E. M., \& Gillespie, J. (2009). How study abroad shapes global careers: Evidence from the United States. Journal of Studies in International Education, 13(3), 382-397. doi: $10.1177 / 1028315308319740$

Office of the Provost for Teaching and Learning. (n.d.). The Wisconsin experience and the essential learning outcomes. Retrieved from http://www.learning.wisc.edu/welo2010.pdf

Oxfam. (n.d.). Oxfam education. Retrieved January 22, from http://www.oxfam.org.uk/education

Paige, R. M., Cohen, A. D., \& Shively, R. L. (2004). Assessing the impact of a strategiesbased curriculum on language and culture learning abroad. Frontiers: The Interdisciplinary Journal of Study Abroad, 10, 253-276. Retrieved from http://www.frontiersjournal.com/issues/vol10/vol10-15_PaigeCohenShively.pdf

Paige, R. M., Fry, G.W., Stallman, E.M., Horne, A., La Brack, B., \& Josic, J. (2007). SAGE survey. Minneapolis, $\mathrm{MN}$ : University of Minnesota. Retrieved from http://www.cehd.umn.edu/OLPD/SAGE/GlobalEngagementSurvey.pdf

Paige, R. M., Fry, G. W., Stallman, E. M., Josic, J., \& Jon, J. (2009). Study abroad for global engagement: The long-term impact of mobility experiences. Intercultural Education, 20(S1-2), S29-44. doi: 10.1080/14675980903370847

Perry, L. B., \& Southwell. L. (2011). Developing intercultural understanding and skills: Models and approaches. Intercultural Education, 22(6), 453-466. doi: $10.1080 / 14675986.2011 .644948$

Redden, E. (2010, July). Academic outcomes of study abroad. Retrieved from http://www.insidehighered.com/news/2010/07/13/abroad

Reilly, D., \& Senders, S. (2009). Becoming the change we want to see: Critical study abroad for a tumultuous world. Frontiers: The Interdisciplinary Journal of Study Abroad, 18, 241 267. Retrieved from http://www.frontiersjournal.com/documents/FrontiersXVIIIFall09-Reilly-Senders.pdf

Rexeisen, R. J., Anderson, P. H., Lawton, L., Hubbard, A. C. (2008). Study abroad and intercultural development: A longitudinal study. Frontiers: The Interdisciplinary Journal of Study Abroad, 17, 1-20. Retrieved from 
http://www.frontiersjournal.com/documents/RexeisenetalFrontiersvolXVIIFall2008.pdf

Rowan-Kenyon, H. T., \& Niehaus. E. K. (2011). One year later: The influence of short-term study abroad experiences on students. Journal of Student Affairs Research and Practice, 48(2), 213-228. doi:10.2202/1949-6605.6213

Salisbury, M. H. (2011). The effect of study abroad on intercultural competence among undergraduate college students (Doctoral dissertation, University of Iowa). Retrieved from http://ir.uiowa.edu/etd/1073/

Sandgreen, D., Elig, N., Hovde, P., Krejci, M., \& Rice, M. (1999). How international experience affects teaching: Understanding the impact of faculty study abroad. Journal of Studies in International Education, 3(1), 33-56. doi: 10.1177/102831539900300104

Sutton, R., \& Rubin, D. (2004). The GLOSSARI Project: Initial findings from a systemwide research initiative on study abroad learning outcomes. Frontiers: The Interdisciplinary Journal of Study Abroad, 10, 65-82. Retrieved from http://www.frontiersjournal.com/issues/vol10/vol10-04_SuttonRubin.pdf

Sutton, R., \& Rubin, D. (2010, June). Documenting the academic impact of study abroad: Final report of the GLOSSARI Project. Paper presented at the NAFSA Annual Conference (Kansas, MO). Retrieved from http://glossari.uga.edu/datasets/pdfs/FINAL.pdf

Teichler, U., \& Janson, K. (2007). The professional value of temporary study in another European country: Employment and work of former ERASMUS students. Journal of Studies in International Education, 11(3/4), 486-495. doi: 10.1177/1028315307303230 University of Indiana. (2009, May). Overseas study at Indiana University Bloomington: Plans, participation and outcomes (Executive Summary). Retrieved from http://www.iu.edu/ - uirr/reports/special/doc/Overseas Study - Executive Summary.pdf Woolf, M. (2010). Another Mishegas: Global citizenship. Frontiers: The Interdisciplinary Journal of Study Abroad, 19, 47-60. Retrieved from http://www.frontiersjournal.com/documents/MWoolf-Frontiers XIX Fall 2010.pdf

\section{APPENDIX A}

\section{Study Abroad Group Participants by Study Abroad Program}

\begin{tabular}{|l|l|}
\hline Location of study abroad program & Participants \\
\hline France (Aix-en-Provence) & $76(28 \%)$ \\
\hline Germany (Bonn, Freiburg) & $74(27 \%)$ \\
\hline India (Madurai, Varanasi) & $3(1 \%)$ \\
\hline Italy (Bologna, Florence) & $9(3 \%)$ \\
\hline
\end{tabular}


Dianna Murphy, Narek Sahakyan, Doua Yong-Yi \& Sally Sieloff Magnan

\begin{tabular}{|l|l|}
\hline Senegal (Saint-Louis) & $21(8 \%)$ \\
\hline Spain (Madrid) & $74(27 \%)$ \\
\hline Thailand (Chiang-Mai) & $6(2 \%)$ \\
\hline TOTAL & $270(100 \%)$ \\
\hline
\end{tabular}




\section{APPENDIX B}

\section{Questionnaire: Global Engagement Items}

Note: Only participants in the Study Abroad Group were presented with questions about their study abroad experiences.

\section{CIVIC ENGAGEMENT}

1. On issues of domestic (local, state, or national) importance I have: (Response options: Frequently, Sometimes, Rarely, Never)

0 given formal talks or demonstrations.

0 organized or signed petitions.

0 written letter(s) to the editor.

o been involved in protests, demonstrations.

0 voted in an election.

0 played a leadership role in improving quality of life.

0 used the Internet to raise awareness about social and political issues.

o made a purchasing decision because of the social or political values of a company.

0 contacted or visited a public official.

2. To what degree do you feel study abroad was helpful in developing your domestic civic engagement?

3. On issues of international importance I have:

(Response options: Frequently, Sometimes, Rarely, Never)

0 given formal talks or demonstrations.

0 organized or signed petitions.

0 written letter(s) to the editor.

o been involved in protests, demonstrations.

0 voted in an election.

o played a leadership role in improving quality of life.

0 used the Internet to raise awareness about social and political issues.

o made a purchasing decision because of the social or political values of a company.

o contacted or visited a public official.

4. To what degree do you feel study abroad was helpful in developing your international civic engagement? (Response options: To a large degree, To some degree, Very little, Not at all)

\section{VOLUNTARY SIMPLICITY}

5. Please complete the following statement: I practice voluntary simplicity... (Response 
options: To a large degree, To some degree, Very little, Not at all)

6. To what degree did your study abroad experiences influence you to practice voluntary simplicity? (Response options: To a large degree, To some degree, Very little, Not at all)

\section{KNOWLEDGE PRODUCTION}

7. During the course of your life and career, have you ever published in print media? For example, have you had your work published as a fiction or non-fiction book; journal, magazine, or newspaper article; governmental or non-governmental organization report; or patent? Yes/No

8. What have you published? Check all that apply.
o Novels/works of fiction
o Magazine articles
o Academic journal articles
o Newspaper articles
o Report (non-governmental or governmental agencies)
o Nonfiction book (scholarly)
o Nonfiction book (trade)
o Translated work
o Educational materials, including curricula
o Patent awards
o Works published in another language
o Publications translated into another language
o Works published with a co-author of another culture or ethnic group
o Publications with an international or intercultural orientation
o Publications that draw upon research using a language gained in study abroad
o Other, please specify

9. During the course of your life and career have you engaged in other types of knowledge production? (For example, artistic work, online publishing, multimedia, or films.) Yes/No

10. What have you published or created? Check all that apply. 
o Web-published articles

o Blogs

o Websites

o Dramatic productions

o Films

o Musical productions

o Artworks (sculptures, paintings, etc.)

o Digital media

o Other, please specify:

11. To what degree do you feel study abroad was helpful in developing your knowledge production activities? (Response options: To a large degree, To some degree, Very little, Not at all)

\section{PHILANTHROPY}

12. Please check how often you have volunteered for the following organization types:

(Response options: Frequently, Sometimes, Rarely, Never)

0 Arts

o Community (e.g., board service)

o Education

o Environment

o Health

o Human Rights (includes women, minority groups, and LGBT)

o International Development

o Poverty (e.g., food bank, construction and repair)

o Religion

o Social Justice

o Youth Organizations (e.g., Scouts, athletic teams)

13. Approximately how many hours have you volunteered per month for any organization?

14. Please complete this statement: "Overall, my level of volunteer work was influenced by my study abroad experience:" (Response options: To a large degree, To some degree, Very little, Not at all)

15. Please check how often you have donated money, assets, or property to the following organization types: (Response options: Frequently, Sometimes, Rarely, Never) 
0 Arts

o Community (e.g., board service)

o Education

o Environment

o Health

o Human Rights (includes women, minority groups, and LGBT)

o International Development

o Poverty (e.g., food bank, construction and repair)

o Religion

o Social Justice

o Youth Organizations (e.g., Scouts, athletic teams)

16. What is the approximate value of money, assets or property that you have donated on a yearly basis?

17. Please complete this statement: Overall, my level of monetary donations was influenced by my study abroad experience: (Response options: To a large degree, To some degree, Very little, Not at all)

\section{SOCIAL ENTREPRENEURSHIP}

18. Have you ever been a social entrepreneur? Yes/No

19. What types of organizations have you created? Choose all that apply.
o Arts
o Community
o Education
o Environment
o Health
o Human Rights
o International Development
o Poverty (e.g. food bank)
o Religion
o Social Justice
o Youth Organizations (e.g. athletic teams)
o Other, please specify:

20. How many organizations have you created?

21. Approximately what percentage of your profits or surpluses do you reinvest for the good of the community? 
22. In a substantive way, have you ever influenced from within a for-profit organization to be socially responsible? Yes/No

23. To what extent have you influenced an organization from within to be more socially responsible? (Response options: To a large degree, To some degree, Very little, Not at all)

24. To what extent did your study abroad experience influence your commitment to promote social responsibility? (Response options: To a large degree, To some degree, Very little, Not at all)

\section{INTERNATIONALLY-ORIENTED LEISURE ACTIVITIES}

25. How frequently do you engage in the following activities for personal enjoyment?

(Response options: Frequently, Sometimes, Rarely, Never)

o Watch films or listen to music in a language other than English

o Host international visitors (e.g. students, guests)

o Read international newspapers, journals or magazines

0 Access foreign websites

o Volunteer or participate in international organizations

o Attend talks or presentations with an international focus

o Go to restaurants to try international cuisine that is new to you

o Cook international cuisine

o Take language classes

o Travel internationally for pleasure

26. Do you maintain friendships with people of cultures different than your own? Yes/No

27. If yes, how many friends?-
o Many
o A few
o One

28. To what degree do you feel study abroad was helpful in developing your internationallyoriented personal enjoyment activities? (Response options: To a large degree, To some degree, Very little, Not at all) 